Critical Sociology 34(3) 339-348

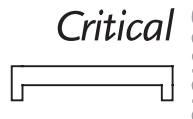

http://crs.sagepub.com

\title{
A Public Sociology for California
}

\author{
Michael Burawoy \\ University of California - Berkeley, USA
}

\begin{abstract}
Some of the most inspiring public sociology takes place at the local level, often hidden from or obscured by professional sociology. Taking inspiration from Edna Bonacich's research with labor and Elizabeth Leonard's research with survivors of extreme domestic violence, this article sketches out what a public sociology for California might mean, and the ways in which professional and critical sociology could support and benefit from such a project.
\end{abstract}

Keywords

California, domestic violence, labor, public sociology

It was the evening of 18 April 2005. I had just finished giving a talk on public sociology in Pasadena. There was a lull in the questions and then Elizabeth Leonard, sociology professor at Vanguard University, ventured her own experiences. A hush came over the room as she spoke of her work with women, imprisoned for killing their abusive partners - research she had been conducting for 10 years with a group called Convicted Women Against Abuse (CWAA). The study was published as Convicted Survivors (Leonard, 2002), a revision of her University of California, Riverside dissertation. Her searing accounts of relentless and vicious abuse had then been turned into a play by Warren Doody, an English professor also teaching at Vanguard University. The play, Life Without Parole (Doody, 2003), was performed in a number of venues, including before the imprisoned women of Leonard's research. It is framed around a parole hearing, an exchange between an uncomprehending and heartless commissioner and prisoners painfully divulging and thus reliving the torture that drove them to murder, how they came to face lifetime sentences for defending themselves. Dramatizing the research in front of the very women with whom she had worked, was for Leonard the highlight of her public sociology. ${ }^{1}$ 
I call this organic public sociology because it involved an unmediated dialogue between a public, in this case the women prisoners themselves, and the sociologist-cum-playwright. Indeed, the sociologist was instrumental in constituting these women as a public, prompting their growing self-consciousness as convicted survivors. More than that, we can say the broader publicity given to the fate of battered women who kill their partners has helped other organizations, such as Free Battered Women, to put pressure on the Governor of California to grant parole to convicted survivors. Whether or not organic public sociology accomplishes its policy goals depends on its popular base and on collaborators with space to maneuver within the state, but such public sociology is important in its own right as promoting political inclusion and democratic deliberation.

\section{The Limits of Policy Sociology}

Digging deeper the story gets more complicated. We should not forget that Elizabeth Leonard's research rested on a burgeoning body of research dealing with domestic violence - its prevalence, its various types, its contexts, its consequences for victims and their children, its paradoxes, etc. Moreover, the study of gender violence was itself inspired by landmark feminist studies, such as those by Susan Griffin (1971), Susan Brownmiller (1975), Diana Russell (1975), and Lenore Walker (1979). The feminist movement supported a critical stance toward what was an extant and outdated professional sociology that had painted the family in all too rosy colors, as an internally integrated unit, based on a harmonious division of labor, effectively performing crucial functions for the wider society. Amazingly, the Journal of Marriage and the Family only began to carry violence as an entry in its index in 1970 . We see how feminist interventions have transformed the face of family sociology.

But coming to terms with domestic violence does not end here. The development of critical and professional research reverberated back into the public realm, intensifying and focusing feminist movements on the abject failure of the state to protect women. When the state did respond, it took over the battered women shelters that had been created by feminist groups. As Nancy Fraser (1989: chapter 8) has argued, such administrative solutions, while well-intentioned and important, nonetheless domesticated the critical impulses of the feminist movement. Although the state performed crucial services for battered women it failed to tackle the problem at its source. There was also progress in the law as it began to recognize wife beating as a criminal act, calling it 'battery'. Lawyers drew on social research to explain why women might be reluctant to defend themselves - 'the battered woman syndrome'. But here, too, progress was Janus-faced. As Elizabeth Leonard shows, the battered woman syndrome has also been turned against those women who were plucky enough to defend themselves against the violence of their abusers. If they deviated from the norm of passivity, then perhaps they had not been abused?

What we see here is a complex interaction among four types of sociology, summarized in Table 1. Let me first formulate the interaction in the abstract. Professional sociology (research evaluated by peers and legitimated as science) and public sociology (sociologists engendering 
Table 1: Sociology's Engagement with Domestic Violence

\begin{tabular}{|l|r|r|}
\hline $\begin{array}{l}\text { Professional Sociology } \\
\text { Research on domestic violence, } \\
\text { prevalence, types, paradoxes }\end{array}$ & $\begin{array}{r}\text { Policy Sociology } \\
\text { Officials, consultants, expert }\end{array}$ \\
\hline $\begin{array}{l}\text { Critical Sociology } \\
\text { Feminist critique of family } \\
\text { studies that missed its } \\
\text { patriarchal, coercive character }\end{array}$ & $\begin{array}{r}\text { Public Sociology } \\
\text { Dialogue shifts language } \\
\text { from wife beating to battery, } \\
\text { raising public consciousness }\end{array}$ \\
\hline
\end{tabular}

dialogue with or within publics about fundamental values in society) are antagonistic and interdependent. They are antagonistic because they are accountable to different norms and audiences. They are interdependent because public sociology requires the input of professional sociology, while the progress of the latter depends on the injection of relevancy and new ideas from the former. Policy sociology is different from public sociology in that it is accountable to and dependent on a client, often becoming a servant of power. Finally, critical sociology discloses the normative, theoretical and methodological assumptions of professional sociology, but it also aims its critical impulses at policy sociology and instills public sociology with values. At the same time it receives inspiration from sociology's public face.

Returning to our particular concerns, sociologists engaged with the women's movement infused critical sociology with feminist sensibilities, which in turn reshaped research agendas of the professionals. Critical and professional sociology fed back into a vibrant public sociology. If these critical impulses from the public sphere are weak, sociologists working within the policy arena, whether as officials, consultants or expert witnesses, find themselves constrained by welfare agencies and legal apparatuses. The way forward is through the renewal of an organic public sociology in civil society, wherein sociologist and public are organically connected, holding policy sociology accountable to its expressed ideals, and thus preventing its capture by the state. As they are connected to thick, active and often counter-publics, I argue that such organic public sociologies are more likely to be built at the local rather than the national level.

\section{Public Sociology: Local and Cosmopolitan}

In disseminating her findings Elizabeth Leonard is undertaking a public sociology for California. Her research was not only conducted in California but it aimed to promote discussion among publics of California. There are many such examples of a public sociology for California; ironically, often invisible to the sociological eye. Making this invisible engagement visible, Andrew Barlow (2007) recently brought together a series of California case studies of collaborative research to promote equal access to schooling, to broaden public consciousness of environmental inequities, and to develop community action research around youth violence. 
These examples, however, are by no means the only form of public sociology done in California. Indeed, the more celebrated examples are of a different character. Take Arlie Hochschild's (1989), The Second Shift or Robert Bellah et al.'s (1985) Habits of the Heart, prototypes of what I call traditional public sociology, aimed at stimulating discussion and debate among broad, inchoate publics rather than with thick, active, counter-publics. The research upon which these books were based was completed in California but little attempt was made to recognize this fact. It could have been done anywhere in the USA, and the audiences were national not specifically Californian publics. To use an old distinction (Merton, 1968: chapter 12), you might think of two types of public sociology - local and cosmopolitan. The former is committed to local audiences with which it has an intense and mutually constitutive interaction whereas the latter rises above context and seeks a more rarified engagement with thinner publics. Given the balance of forces within the national media and its public sphere, local public sociology - a public sociology for California - is more likely than the cosmopolitan variety to reap immediate dividends in challenging the state and expanding political participation.

There is a third, intermediary category of public sociology, between public sociology in California and public sociology for California, what we might call public sociology of California in which there is sensitivity to the local research context while the publics being addressed are far broader. Thus, one frequent strategy is to publicize California either as the great exception or as a bellwether for the rest of the USA. Studies that are self-consciously and explicitly about California become the subject of debate outside as well as within California. You might think of the Master Plan for higher education in California, designed by sociologist manqué, Clerk Kerr, and subject to the wrath of the New Left as the coming of the university as factory. At that time it was a controversial vision that was exported to other states in the USA and beyond, now it is a distant utopia. Indeed, sociologists are more likely to focus on the plummeting quality of California higher education and link it to rising rates of incarceration, the staggering increase in numbers of prisons built at the cost of public education. The penal state, as Loïc Wacquant (2007) calls it, locks up minority youth of color at a genocidal rate, famous for such policies as 'three strikes and you are out' - models, dreamt up by criminologists that California now exports to the rest of the country and, indeed, the rest of the world. Or, on a different note, you may think of the labor research of Ruth Milkman $(2000,2006)$ and the associates of the state-wide Miguel Contreras Labor Program. They have studied the resurgence of unions in California, especially in Los Angeles among immigrant workers in the service sector, as a model that has been discussed and emulated elsewhere in the country.

Thus, a public sociology of California takes local studies and produces a cosmopolitan message, much as the Chicago School of urban sociology projected itself to all corners of the earth, challenging others to come up with models and theories of their own urban locality. With local roots and cosmopolitan visions public sociologies of California have been surprisingly influential. 


\section{The Trouble with Professional Sociology}

What are the conditions and possibilities of such public sociologies of and for California? Who are the pioneers of such public sociologies? We actually do not think of sociologists but journalists such as Carey McWilliams and Peter Schrag, geographers such as Richard Walker, intellectuals at large such as Mike Davis, educationalists such as Jeannie Oakes, economists such as Paul Taylor, even novelists such as John Steinbeck and Upton Sinclair. These are the people we spontaneously think of when we think of influential social commentary on California. But why not sociologists?

The answer, at least in part, lies in the character of professional sociology, designed for peers not publics. US sociology, in particular, has been remarkably unselfconscious about the spatial and historical context of its studies. Indeed, professional sociology has made its goal the discovery of patterns that transcend history and geography. Thus, if we think specifically of professional sociology as it developed in post-WWII California, we might delineate two traditions. There are the varieties of micro-sociology from experimental social psychology to symbolic interaction and ethnomethodology - all of which bracket temporal and spatial contexts, indeed make a fetish out of such bracketing. Whether it be Goffman, Garfinkel or Berger the point is to seek out general claims about human interaction that apply across time and space. The other tradition is a comparative and historical sociology, associated with such establishment figures as Seymour Martin Lipset, Reinhard Bendix, Neil Smelser, and Robert Bellah who may offer historical perspectives but their unit of analysis is never California but the nation state. Thus when Bendix and Lipset write their classic treatise on social mobility they completely overlook the fact that it was based on interviews done in Oakland, California. When Lipset studies student rebellion at Berkeley, the specificity of Berkeley and California is quickly lost. These are all cosmopolitan sociologists aiming at national or international audiences. Indeed, many of the sociologists who built the departments at the University of California migrated from the East or the Mid-West to California in the late 1940s and 1950s. They came in search of professional status and lavish conditions offered by the expansion of higher education in the Golden State, but they were not interested in California per se but in their standing among their peers and teachers whom they had left behind. Without a regionally self-conscious professional sociology we are handicapped in building a public sociology for or, indeed, of California.

In thinking of a professional sociology that focuses on California, it might be worthwhile to return to one of its pioneers, or you might say one of its anti-pioneers. Frederick Teggart was an austere, conservative and irascible self-made academic. ${ }^{2} \mathrm{He}$ began as a librarian, before moving into Berkeley's history department and from there was ejected into the department of political science. Wherever he went he created turmoil. So as to keep him from disrupting other departments, he was given his own Department of Social Institutions, which he headed from 1923 until 1941. He was adamantly opposed to sociology, which he likened to the dance of the seven veils, taking them off one by one until in the end there was nothing to be discovered. He scornfully dismissed the focus on muckraking that, in his opinion, defined the Chicago 
School bedeviled by narrow concerns and historical myopia. Opposed to sociology as he knew it, Teggart and his colleague Margaret Hodgson held up the founding of the Berkeley department until his death in 1946.

That is not to say his research was not sociological. Far from it. Teggart was interested in discerning global patterns of human migration across history, but especially in the ancient world. Today we might recognize him as a forerunner of world systems theory. But he also understood California in its specific geographic location, connecting Europe to Asia and the Americas. Reflecting its geographical place in a global order, the meeting ground of so many races and nationalities, he argued for self-conscious regional studies of California. We could do worse than return to some (!) of his ideas.

\section{The Missing Regional Sociology of California}

So how should sociology think of California today? First, we note that California is still a junction between East and West, and North and South. Of all the US states it remains the most heavily populated by immigrants, over a quarter (28\%) of its 36 million inhabitants are foreign born, and of these a third are from Asia and over a half from Latin America. Here in our state multitudes from all over the world meet and generate California's fault lines. So second, we should not homogenize California, we should recognize its internal complexity. In depicting California’s racial fault lines, Tomás Almaguer (1994) describes the origins of white supremacy, the subjugation of Hispanic populations, the importation of cheap immigrant labor, and the destruction of Native American populations. One might also draw attention to the power of California agribusiness and its peculiar labor institution, recalling to mind Carey McWilliams's Factories in the Field (1939), but also the more recent work of such sociologists as William Friedland, Robert Thomas and Miriam Wells who have studied the organization of agricultural production.

Just as there is a fault line between East and West, agriculture and industry, so too there is one between North and South, most recently explored by Ruth Milkman and Rachel Dwyer (2002) who point to the different dynamics of job creation - high end, high skill jobs in the North, low end, low skill jobs in the South. You might say that California in some respects replicates the divide between global North and global South, advanced technology at the pole of dynamic accumulation in the Silicon Valley as opposed to declining industry, immigrant sweatshop labor alongside staggering wealth produced by the entertainment industry in the South. Related to these developments is the surge of labor organizing, referred to above, among immigrant workers, especially in Los Angeles.

To get at the peculiarity of California is not only to recognize its diversity, its fault lines but, as Teggart insisted, to situate California in its wider national and global context. One can do this by explicit comparisons, such as Annalee Saxenian's (1994) comparison of the dynamism of Silicon Valley with the stagnation of the similar Route 128 in Massachusetts. Or one can compare California with other parts of the world as I did long ago when I compared the migrant labor system between Mexico and California with the 
migrant labor system of apartheid South Africa. More recently, Pierrette HondagneuSotelo (1994 and 2001) has advanced our understanding of the labor connections between California and Latin America through her analysis of gendered streams of migration from Mexico. California could become host to a range of studies that pay attention to the link between the local and global, seeing California as a veritable global hub, growing in importance as the center of gravity of the world economy moves toward Asia. The research strategy is to situate California within its internal dynamics and its global determinations, and not to eclipse its peculiarity in the search for transspatial, transhistorical generalization.

A public sociology of California will require a professional sociology of California, it will require us to be explicit about, rather than suppress, the peculiarities of the contexts within which we do research. California publics are no more interested in generalities across time and space, than patients are interested in the etiology of disease. For example, California publics want to know the implications of ballot initiatives: making union contributions to political campaigns subject to membership approval; of requiring teenagers to secure parental approval for abortions; of turning power to redraw electoral districts from legislators to retired judges; of lengthening the probationary period of public school teachers; of capping state spending while giving the governor extensive budgetary powers. ${ }^{3}$ We should be able to draw on our bank of sociological knowledge and work out the implications of each of these issues and in that way promote public debate and discussion. This is, indeed, what the Public Policy Institute of California does investigates public issues for public consumption. All too rare though it may be, it should nevertheless be common practice among California's sociologists.

\section{The Power of Critical Sociology}

A public sociology requires and inspires professional sociology. Public sociology has no identity without the impetus of the cumulative body of sociological research, just as public sociology always poses exciting challenges for professional sociology, pushing it in new directions. But the two are also in obvious tension: public sociology speaks to publics, it has to be relevant and it works through dialogue, while professional sociology speaks to sociologists, it wrestles with the puzzles of research programs, seeking theories with greater correspondence to reality. What holds the two together in antagonistic interdependence, is a critical sociology.

This special issue is dedicated to Edna Bonacich and her life underscores the importance of critical sociology both for her professional sociology and her public sociology. ${ }^{4}$ Bonacich's entry into the world of professional sociology was marked by her now classic essays on the split labor market - the existence of a racialized labor force in which capital constructs and exploits the division between high and low priced labor. Inspired by her experiences in South Africa where she first developed her critical Marxist impulse, she explores the configurations of the split labor market in different national contexts. Those same critical impulses led her to develop close relations with California labor, working 
with garment workers' trade unions in Los Angeles, helping them understand the global context within which they operated as well as helping to design the boycott of Guess.

Despite deep organic and dialogic connection with labor she has managed to resist overtures from labor that would compromise her independence and turn her into a policy sociologist. Thus, Bonacich and Applebaum (2000) situate the dilemmas of organizing Californian garment workers in their detailed analysis of the transnational chain of apparel production and distribution. From here it was a short step to her 'global logistics' approach to labor organizing that identifies the weakest link in global distribution chains. Thus, in Los Angeles she singled out independent truckers at the booming ports of Los Angeles and Long Beach, as ripe for unionization. With a taste for independent research, Bonacich nonetheless always takes labor's interests as point of departure. Her critical perspectives allow her to hover between professional and public sociology, becoming a local with cosmopolitan visions. ${ }^{5}$

Her teaching also exemplifies the development of an organic public sociology within the university. She organizes classes around 'class projects', research focused on pressing local issues, such as the collusion of university and the corporate world in creating urban marginality, or the consequences of racial segregation in local schools, or police violence in the local Chicano community. In addition to teaching the practice of public sociology, there is also the practice of teaching as public sociology, that is to say constituting students themselves as a public. This means taking the lived experience of students as a point of departure and building it into a consciousness of the broader forces that shape it, by compelling first, a dialogue between students' lived experience with the sociological literature, second a dialogue among students about their own different experiences, and third, a dialogue between students and wider publics beyond the classroom. These three dialogues take place simultaneously and are in dialogue with each other. It can make the most abstruse sociology exciting and immediate, not just for students but also for the publics they reach.

We cannot expect the major research universities to develop a public sociology for California. At private but also public universities of national or international standing, with some notable exceptions, faculty have their eyes on national recognition and national publics. They are unabashedly cosmopolitan and if they do their sociology in California they are most likely to bury that context. Brave souls like Edna Bonacich, keen on an organic public sociology, are likely to be shunned by their mainstream colleagues for refusing to limit themselves to professional sociology, for exploring controversial issues that might bring the university into disrepute, for 'politicizing' and endangering our discipline, for going local. But their sociology is no less rigorous, no less embedded in research programs - it simply draws inspiration from local publics, and engages those publics on their own terrain.

A public sociology for California will more likely come from energetic faculty in the state system or at community colleges, attuned to local issues. Like Elizabeth Leonard and her partnership with Warren Doody, they will be more adept at developing an organic public sociology. Indeed, an embryonic public sociology for California can be found in California's Social Problems (Hohm and Glynn, 2002), a volume produced by dedicated teachers of sociology. Organic public sociology is also more likely to emerge 
from sociologists embedded in inter-disciplinary programs of Ethnic Studies, AfricanAmerican Studies, Native American Studies, and Women's Studies, whose raison d'etre leads them to close connections and identification with the publics they represent within the academy. As the university - public and private - becomes more corporatized from above, so an organic public sociology has to flourish from below.

\section{Acknowledgements}

This is a revised version of an address I gave to the California Sociological Association, Sacramento, 11 November 2005. Thanks to the editors of this special issue for their suggestions and comments.

\section{Notes}

1 Since then Leonard (forthcoming) has completed her own analysis of her engagement with convicted survivors.

2 Grace Dangberg (1983) has brought together a collection of Teggart's writings that cover his life work.

3 These were the measures up for the vote in the election of 8 November 2005.

4 I'm drawing on Edna Bonacich's (2005) wonderful account of her career as an organic public sociologist.

5 Bonacich seems to have put her split labor market analysis behind her, perhaps distancing herself from her more 'professional' life. Writing in this issue, Jennifer Chun (2007), however, demonstrates the importance of reconstructing that earlier analysis for a global context. Contrary to the anticipation of Bonacich, Chun shows how capital (together with the state) has crushed upper tier labor, forcing union federations to assist lower tier labor (low paid immigrant, female, racialized labor) in organizing itself through symbolic politics. This is happening not just in the USA but throughout the world.

\section{References}

Almaguer, T. (1994) Racial Fault Lines: The Historical Origins of White Supremacy in California. University of California Press: Berkeley.

Bellah, R., Madsen, R. Sullivan, W.M., Swidler, A. and Tipton, S. (1985) Habits of the Heart: Individualism and Commitment in American Life. University of California Press: Berkeley.

Barlow, A. (2007) Collaborations for Social Justice: Professionals, Publics and Policy Change. Rowman and Littlefield: Lanham.

Bonacich, E.M. (2005) Working with the Labor Movement: A Personal Journey in Organic Public Sociology. The American Sociologist 36(3/4): 105-20.

Bonacich, E.M. and Applebaum, R.P. (2000) Behind the Label: Inequality in the Los Angeles Apparel Industry. University of California Press: Berkeley.

Brownmiller, S. (1975) Against Our Will: Men, Women and Rape. Ballantine: New York. 
Chun, J.J. (2007) The Limits of Labor Exclusion: Redefining the Politics of Split Labor Markets under Globalization. Critical Sociology 34(3) (this issue).

Dangberg, G. (ed.) (1983) A Guide to the Life and Works of Frederick J. Teggart. The Grace Dangberg Foundation: Reno.

Doody, W. (2003) Life Without Parole. Unpublished manuscript, Vanguard University, California.

Fraser, N. (1989) Unruly Practices. University of Minnesota Press: Minneapolis.

Griffin, S. (1971) Rape: The All-American Crime. Ramparts 10(3): 26-35.

Hochschild, A. (1989) The Second Shift: Working Parents and the Revolution at Home. Viking Press: New York.

Hohm, C.F. and Glynn, J.A. (2002) California's Social Problems, 2nd Edition. Pine Forge Press: Thousand Oaks.

Hondagneu-Sotelo, P. (1994) Gendered Transitions: Mexican Experiences of Immigration. University of California Press: Berkeley.

Hondagneu-Sotelo, P. (2001) Doméstica: Immigrant Workers Cleaning and Caring in the Shadow of Affluence. University of California Press: Berkeley.

Leonard, E. (2002) Convicted Survivors: The Imprisonment of Battered Women Who Kill. State University of New York Press: Albany.

Leonard, E. (forthcoming) Returning Research to Convicted Survivors: From Data to Drama. V. Jeffries (ed.) Handbook of Public Sociology. Rowman and Littlefield: Lanham.

McWilliams, C. (1939) Factories in the Field: The Story of Migratory Farm Labor in California. Little, Brown: Boston.

Merton, R. (1968) Social Theory and Social Structure. Free Press: New York.

Milkman, R. (ed.) (2000) Organizing Immigrants: The Challenge for Unions in Contemporary California. ILR Press: Ithaca.

Milkman, R. (2006) L.A. Story: Immigrant Workers and the Future of the U.S. Labor Movement. Russell Sage Foundation: New York.

Milkman, R. and Dwyer, R. (2002) Growing Apart: The 'New Economy' and Job Polarization in California, 1992-2000. The State of California Labor 2002, pp.3-36. University of California Press: Berkeley. URL (consulted 15 October 2007): http://repositories.cdlib.org/cgi/viewcontent.cgi?article $=1002 \&$ context $=$ ile

Russell, D. (1975) The Politics of Rape: The Victim's Perspective. Stein and Day: New York.

Saxenian, A. (1994) Regional Advantage: Culture and Competition in Silicon Valley and Route 128. Harvard University Press: Cambridge.

Wacquant, L. (2007) Deadly Symbiosis. Polity Press: New York.

Walker, L. (1979) The Battered Woman. Harper Perennial: New York.

For correspondence: Michael Burawoy, Department of Sociology, University of California, Berkeley, CA, 94720, USA. Email: burawoy@berkeley.edu 